\begin{tabular}{lcr}
\hline & ANNALES \\
& & \\
UNIVERSITATIS MARIAE CURIE-SKLODOWSKA & \\
LULLIN - POLONIA & SECTIO M & 2021 \\
\hline
\end{tabular}

\author{
Vasyl Karpo \\ Yuriy Fed'kovych Chernivtsi Natonal University, Ukraine \\ v.karpo@chnu.edu.ua \\ ORCID: https://orcid.org/0000-0002-7828-6980
}

Nataliia Nechaieva-Yuriichuk

Yuriy Fed'kovych Chernivtsi Natonal University, Ukraine

n.nechayeva-yuriychuk@chnu.edu.ua

ORCID:http://orcid.org/0000-0001-5882-7121

\title{
Security Challenges of Modernity: Russian Federation Information Activity on the Backdrop of a Pandemic Covid-19
}

\section{Introduction}

From the ancient times till nowadays, humanity has faced a number of challenges, between which security has played a crucial role. The dynamics of changes in approaches of understanding security can be schematically described as follows: from individual, through collective and state, and again to individual in a new measurement (synchronized with collective and state). Information and communication technologies play special roles in these processes. The first forms of communication (drawings, writing, the printing press, telegraph, telephone, radio and television) were steps toward the contemporary global information space with Internet connection and modern technological capabilities of lightning-fast communication.

Today's technologies have opened up both new opportunities and new challenges to humanity. Indeed, the advent of the Internet and, consequently, various messengers and social networks have promoted the establishment and 
development of family contacts, regardless of geolocation, health problems (donor search), self-education and more. Ideally, it has also allowed the flow of knowledge and awareness across distances.

In today's pandemic times, the usage of new information technologies has contributed to reformatting the workspace and schedule, yet, from another point of view, the technological breakthrough has generated new conditions for political processes and provoked unpredictable consequences for security all over the world. The open networking of the Internet has facilitated the intensification of actions of positive civil disobedience such as "Arab Spring", Revolution of Dignity in Ukraine, mass protests in Belorussia etc. Moreover, the algorithms of social networks were and are still using by different political actors, for example, by Barak Obama and Donald Trump in the USA. It has also been applied in the negative sense as a means of spreading propaganda.

The second decade of XXI ${ }^{\text {st }}$ century has expanded the scope of the traditional vision of security in the global and individual dimensions. In recent times, humanity waited anxiously the centenary of the 'never again' First World War. Yet, 2014 was the year that repeated the experience of 1914: the annexation of Ukrainian territory, and brought worries of 1938, appeasement and the destruction of Czechoslovakia - but this time in a Ukrainian setting - to placate a neighbour's delusions. The further military aggression of Russian Federation was accompanied by a powerful information campaign where only Russia recognized itself as the subject. All other states and their citizens, of course, were and still are the objects of it.

In 2019, Covid19 became the top-news in a world. The pandemic of SARSCoV-2 completely changed the attitude to the organization of work and leisure. Virtualization has become the fundamental basis of contemporary life - and one that has been taken advantage of for ill-purposes by certain political actors, like the Russian Federation.

Contemporary problems of socio-political transformations have become the subject of scientific researches of many scientists. Columbia University professor Marianne Hirsch first used the term "post-truth" as a definition of modernity. She emphasized that the descendants of eyewitnesses of large-scale political movements, events, etc. often feel the impact of these events on their own personal formation. So, between witnesses / participants of events and subsequent generations (children, grandchildren, etc.), the so-called "associative" post-memory is formed - "the result of simultaneity and connection of the first and second-third generations"1.

1 Хирш М.. Что такое постпамять, https://urokiistorii.ru/article/53287 [accessed April $21,2021]$ 
Several scholars have paid attention to the problem of the pandemic influence of social, political, security, informational and other processes of modernity. These include: Francis Fukuyama ${ }^{2}$, Nina Jankowicz and Henry Collis ${ }^{3}$, Ryan J. Scott, Odelle J.Means and Patricia M. Shields ${ }^{4}$ and others. In Ukraine, a number of analytical materials and conferences were produced regarding this notion since the start of pandemic ${ }^{5}$, and the influence of pandemic both on humans being and social, political, economic, mental spheres of life will be the main topic for further researches of scientists in different fields.

The main aim of the article is to analyze the security challenges in the light of pandemic Covid-19 and Russian Federation mis-information activity.

\section{Russia's modern hybrid war, origin and first active steps}

Covid-19 has become a kind of watershed: nowadays, we are talking about the world before and after the pandemic. The social-political processes that have been started before 2020, acquired new significance in the light of the pandemic. For example, the Russian-Ukrainian relations have been radically changed during last decade. The Presidency of V.Yanukovich was marked by returning to authoritarianism and the Russian-oriented vector of Ukrainian policy. His refusal to sign the Association Agreement between the EU and Ukraine led to the mass protests that resulted in bloodshed and political regime change. But the Russian Federation did not recognize the right of Ukrainian people to choose their own way of life. So, Russia began military and information aggression against Ukraine and its willingness to become part of the western world. This aggressive policy was and is still provided on several levels: internal Russian, internal Ukrainian, international in at least two dimensions: formation of a negative image of

2 Fukuyama, Francis. 2020. The Pandemic and Political Order. It Takes a State. https://www. foreignaffairs.com/articles/world/2020-06-09/pandemic-and-political-order [accessed April 18, 2021].

3 Jankowicz,N. and Collis H., Enduring Information Vigilance: Government after COVID-19, in The US Army War College Quarterly: Parameters, 2020, 50 (3), p. 17-31.

4 Scott, J. R., Means J.O., and Shields M.P. The COVID-19 Enemy is Still Advancing, in The US Army War College Quarterly: Parameters, 2020, 50 (3), p. 33-43.

5 ВАовиченко В., Воротнюк, Гарсимчук С., Коваль Н., Краєв О. Пандемія Covid-19 в $Є С$ : егоїзм, соліАарність чи поширення впливу?, Київ 2020, 55 с.; Веселовський А., Александров О., Орлик В. Вплив пандемії Covid-19 на розвиток глобальних процесів розвитку системи міжнародних віАносин, https://niss.gov.ua/sites/default/files/2020-05/ covid-i-globalni-procesy-1.pdf [accessed March, 21, 2021]; Спеціальна доповідь уповноваженого Верховної Ради України з прав АюАини «Вплив пандемії Covid-19 на ромську громаду в Україні, Київ 2021, 29 с., https://rm.coe.int/special-report-11-01-2021-ukr/1680a13218 [асcessed April, 31, 2021] 
Ukraine and interference in the internal affairs of other countries through the use of innovative information technologies.

It is necessary to point out that Russia spread its propaganda both through traditional and innovative technologies. Mass events, leader's speeches, cultural and artistic events, and all sorts of media are among the channels for spreading propaganda ideas. A special place is occupied by government funding of advocacy programs in various fields: from education, to the activities of nongovernmental organizations and, of course, appeals to public opinion, the actual recoding of their ideas and views. Since 2014, Ukrainian society has become the permanent object of Russian propaganda, the aim of which is the formation of new - or consolidation of old - stereotypes both in Ukrainian society and about Ukraine in general.

During the revolutionary events in Ukraine (2013-2014), an aggressive information campaign was waged against the European vector of Ukrainian policy. After V. Yanukovich fled, open military aggression against Ukraine began: so called "green people" appeared in the Autonomous Republic of Crimea and soon after that the buildings of Supreme Council and Council of Ministers of Crimea were occupied by pro-Russian powers. Active preparations toward a referendum on Crimean statehood then began to legitimize the new regime, and available historical and political information had taken on a very Russian stance.

The main propaganda technologies that were used in Crimea in this endeavor can be clarified as traditional. Images of the Second World War were in active use. For example, billboards:

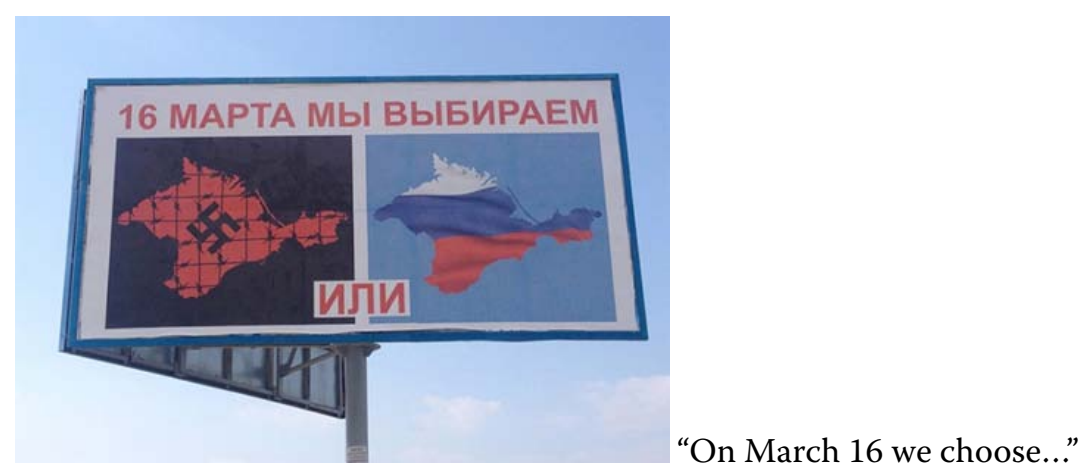

Source: http://www.ostro.org/general/politics/articles/440058/

Also, other visual imagery was supplied that was intended to bring the Crimean people to the conclusion that "Russia is their native home": 


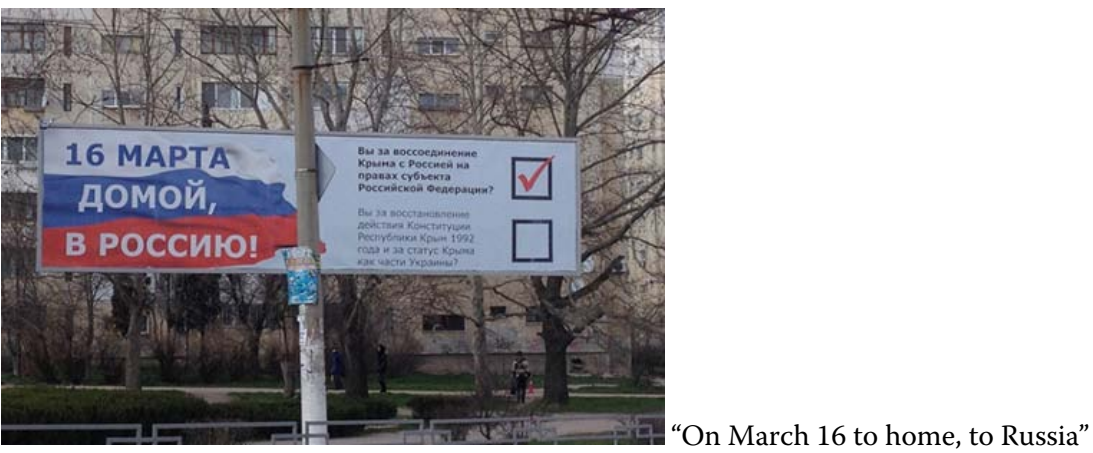

Source: http://www.ostro.org/general/politics/articles/440058/

By the results of the referendum announced by Russia, around $96 \%$ of all Crimea residents voted for the $\mathrm{RF}^{6}$. Due to these falsified results, the state sovereignty of Ukraine was violated: Crimea was rapidly included in the structure of the Russian Federation.

The next events in Ukraine unfolded fairly quickly: further military aggression on its eastern borders, a wide campaign against Ukraine's sovereignty in Ukrainian and international media, provocations etc. From 2014 till now, the world sees an open hybrid war against Ukraine by the Russian Federation. Firstly, it was provided totally against Ukraine, but after the imposition of sanctions, the strategic aims of it, in our point of view, were extended.

In 2014, the countries of the European Union and the United States became the objects of Russian aggressive informational policy, which was provided on different levels. For publicity, the most famous activities were the interference in the presidential elections in the United States and France, referendums in Catalonia and Scotland etc.

As a result, the gap between democratic and authoritarian approaches in world politics has widened, and opposition in the international arena between Russia and Western democracies has intensified. As an outcome, in 2015, the European Union launched an active "campaign to combat disinformation disseminated by the Kremlin"7, which has been carried out by the European External Action Service. On a regular basis, the analysis of information disseminated by Moscow in different languages is undertaken in order to identify misinformation

6 Фаріон I. Результати референдуму у Криму Росія «намалювала», http://wz.lviv.ua/ ukraine/126861 [accessed May, 1, 2021]

7 Смотряєв М. Що таке глибокі фейки і як 3 ними боротися, https://www.bbc.com/ ukrainian/features-43651430 [accessed April 22, 2021]. 
and fake news, including deep ones. Moreover, throughout the Western world, over the years, many different centers and structures have been established to detect misinformation and organize counters to it. In many cases, the source of misinformation is immediately recognized as Moscow-sourced, both de jure and de facto ${ }^{8}$.

It can be said, then that the Revolution of Dignity in Ukraine can be defined as the turning point in world order transformations. If, in 2008, the European Union and world community were not ready for active resistance to Russian aggression in Georgia, in 2014, a sanction policy was launched. This has led to vast changes both in internal and external policy of the Russian Federation and its activity on world arena. Moreover, it opened a new epoch in world development where information has become the basis of all activities in fact.

Covid-19 pandemic as a tool for interference in internal affairs of sovereign states

Since the start of the pandemic, the Covid-19 topic has become top-news all over the world. The uncertainty concerning the origin of the coronavirus, ways of its spread, prevention measures, etc. were used by definite political actors (like Russian Federation) and disinformation on it has been actively spread all over the world. The pandemic of hitherto unknown virus opened the additional possibilities for the creation of an atmosphere of fear and panic among the masses. In each region, fake-news makers take into account certain cases and features of the mentality, so the psychological peculiarities of human beings were and are still actively employed by makers of new manipulative myths and fake news providers.

Discrediting Ukraine gained new momentum after the discovery of the new virus, and the propagandistic idea about "intolerance of Ukrainian society and its non-compliance with European values and standards" acquired new forms. The psychological reactions of people regarding the new illness and uncertainty of its consequences were used by propagandists for undermining the democratic foundations and confidence in democracy itself. Manipulative information technologies, together with provocations that were used in Novy Sanzhar (Ukraine) became the reason of transformation of this settlement into a modern Ukrainian Armageddon'. Stories about the terrible situation in Spain with millions of

8 Ковач О. Велика Британія допоможе Польщі боротися з російськими фейками, https://www.radiosvoboda.org/a/velyka-brytaniya-dopomozhe-polshchi-borotysya-zrosiyskymy-feykamy/29669484.html [accessed December 22, 2021].

9 Величко $\Lambda$. Майстри паніки. Як проросійська мережа в Україні організувала бунт в Нових Санжарах, https://texty.org.ua/articles/100356/specoperaciya-imeni-portnova-ta- 
death $\mathrm{s}^{10}$ intimidated the world community and were used to reconsider the role of democracy in protecting the fundamental human right to security.

At the beginning of 2020, a number of different articles, analytics etc. concerning the ways of counteraction to the spread of Covid-19 appeared in mass media, especially in the Russian and Ukrainian languages ${ }^{11}$. Questions concerning the efficiency of political regimes arose in many of them. It is worth mentioning that in many articles and media messages, the accent was on the effectiveness of the authoritarian states like China in countering the pandemic's effects, for instance, and the ineffectiveness of democracies to protect their citizens from the spread of this unknown disease. Moreover, other fake ideas spread in frames of conspiracy theories concerning coronavirus were about the origins of the viruses etc. At the beginning of spring 2021, more than $70 \%$ of all Ukrainians were sure that the coronavirus was man-made in Western labs ${ }^{12}$. Such ideas of conspiracy were and are still being spread by Russia's propagandistic machine to demonstrate the failure of democracy in times of challenges and threats. Indeed, in post-Soviet space, we witness the spreading of ideas about "happy Soviet times" - of political stability and certainty - but with the absence of reminder of the authoritarian regime behind it and its corruption and inefficiency.

In parallel, Russia's active information policy in Western Europe and the United States in this context is ambiguous. On the one hand, there is a constant attack on democracy as a basis for strategic development of states wherein a number of media messages emphasize the necessity of a revising the understanding the democracy and its role in modern social development. On the other hand, theses about the importance of Russia as a good neighbor to the $\mathrm{EU}$ are distributed to European society. Between them there are the messages about Nord Stream-2 as the basis of Europe's energy independence, as well as the need to establish a constructive dialogue between the EU and Russia, etc., which in turn contributes to strengthening at least the positive image of Russia.

shariya-yak-rozhanyaly-paniku-v-novyh-sanzharah-i-hto-za-cym-stoyit/ [accessed May 10, 2021].

10 Черецький В. та Білик. Іспанія знову перетворюється на осередок поширення коронавірусу. https://cutt.ly/qkhhDvv [accessed April 21, 2021].

11 Асмолов К. В глубокой изоляции. Северная Корея утверждает, что победила коронавирус. Как самая закрытая страна борется с пандемией? https://lenta.ru/articles/2020/05/27/korondr/ [accessed December 24, 2020]; Артамонов А. Кто кучше справляется с пандемией - авторитарные режимы или миберальные Аемократии? https:// republic.ru/posts/96376 [accessed April 24, 2021].

12 Більше 70\% українців впевнені, що ковіА створили штучно, - соцопитування «Рейтингу», https://lb.ua/society/2021/03/25/480743_bilshe_70_ukraintsi_vpevneni_shcho. html [accessed May, 11, 2021] 


\section{Conclusions}

In a short period of time, coronavirus has become an additional tool of informational influence on society. Feelings of panic, fear, anxiety and insecurity have become dominant in different countries. Although the World Health Organization has made a number of recommendations to protect the mental state of people, and experts have welcomed them ${ }^{13}$, a large part of the population is frustrated and needs special assistance. In such a situation, they can be manipulated by different political actors through media and other channels. The natural consequences of this situation are, for instance, demonstrations against quarantine restrictions in various parts of the world.

In a short time, coronavirus has been be used as a tool of informational influence on the mental state of the population. This problem has become the subject of close attention in different parts of the world. Nowadays, in different European states (like the United Kingdom, for example), special departments or institutions to combat misinformation have been established. In addition, various media literacy programs and projects have been implemented in European states, including Ukraine, with the purpose of debunking the political myths and misinformation spread by Russia on Covid-19 and other issues.

It should be emphasized that the widespread misinformation about the coronavirus and its connection with the models of political behavior and political participation of citizens requires a thorough analysis and further research. For example, despite the emergence of scientific intelligence and journalistic materials ${ }^{14}$, which denigrates the halo of success of authoritarian regimes, part of Ukrainian society believes in the man-made Western origin of coronavirus and its deliberate spread ${ }^{15}$.

Dissemination of misinformation about the coronavirus is one of the important tools applied in influencing the world community in the context of national, regional and global development perspectives. The destructive activity of the Russian Federation and unification of democracies in its opposition to this are parallel tensions in the contemporary world. A new geopolitical reality is form-

13 Брюер К. Коронавирус: как защитить свою психику в условиях пандемии. https:// www.bbc.com/russian/features-51912806 [accessed April 27, 2021].

14 Коронавірус: хто ефективніший - Аемократії чи авторитарний Китай, https://www. bbc.com/ukrainian/features-51908010 [accessed December 24, 2020].

15 Грушецький, Антон. Аумки і погмяАи населення України щодо походження коронавірусу і його поширення у світі: травень-червень 2020 року. http://kiis.com. $\mathrm{ua} /$ ?lang $=\mathrm{ukr} \& \mathrm{cat}=$ reports $\& \mathrm{id}=952 \&$ page $=1 \& \mathrm{t}=7 \& \mathrm{fbclid}=\mathrm{IwAR} 3 Q$ O5YGXWTwKPaQQZDa mL83sb-351YQ-fKSkVwrzjRxDeyWqDcccHxTYxo [accessed December 28, 2020]. 
ing. Hence, it is possible to state that we are in the process of implementing a new approach to living that is based on a holistic perception of the unity and vulnerability of our world.

\section{Bibliography}

- Fukuyama, Francis. 2020. The Pandemic and Political Order. It Takes a State. https:// www.foreignaffairs.com/articles/world/2020-06-09/pandemic-and-political-order [accessed April 18, 2021].

- Jankowicz,N. and Collis H., Enduring Information Vigilance: Government after COVID-19, in The US Army War College Quarterly: Parameters, 2020, 50 (3), p. 17-31.

- Scott, J. R., Means J.O., and Shields M.P. The COVID-19 Enemy is Still Advancing, in The US Army War College Quarterly: Parameters, 2020, 50 (3), p. 33-43.

- Асмолов К. В глубокой изоляции. Северная Корея утвержАает, что победила коронавирус. Как самая закрытая страна борется с пандемией? https://lenta. ru/articles/2020/05/27/korondr/ [accessed December 24, 2020]; Артамонов А. Кто кучше справляется с пандемией - авторитарные режимы или киберальные Аемократии? https://republic.ru/posts/96376 [accessed April 24, 2021].

- Більше 70\% українців впевнені, що ковіА створили штучно, - соцопитування «Рейтингу», https://lb.ua/society/2021/03/25/480743_bilshe_70_ukraintsi_vpevneni_shcho.html [accessed May, 11, 2021]

- Брюер К. Коронавирус: как защитить свою психику в условиях пандемии. https:// www.bbc.com/russian/features-51912806 [accessed April 27, 2021].

- ВАовиченко В., Воротнюк, Гарсимчук С., Коваль Н., Краєв О. Пандемія Covid-19 в $\in C$ : егоїзм, соліАарність чи поширення впливу?, Київ 2020, 55 с.;

- Величко $\Lambda$. Майстри паніки. Як проросійська мережа в Україні організувала бунт в Нових Санжарах, https://texty.org.ua/articles/100356/specoperaciya-imeniportnova-ta-shariya-yak-rozhanyaly-paniku-v-novyh-sanzharah-i-hto-za-cym-stoyit/ [accessed May 10, 2021].

- Веселовський А., АлексанАров О., Орлик В. Вплив пандемії Covid-19 на розвиток глобальних процесів розвитку системи міжнародних відносин, https://niss.gov. ua/sites/default/files/2020-05/covid-i-globalni-procesy-1.pdf [accessed March, 21, 2021];

- Ковач О. Велика Британія допоможе Польщі боротися з російськими фейками, https://www.radiosvoboda.org/a/velyka-brytaniya-dopomozhe-polshchi-borotysyaz-rosiyskymy-feykamy/29669484.html [accessed December 22, 2021].

- Коронавірус: хто ефективніший - демократії чи авторитарний Китай, https:// www.bbc.com/ukrainian/features-51908010 [accessed December 24, 2020].

- Смотряєв М. Що таке глибокі фейки і як з ними боротися, https://www.bbc.com/ ukrainian/features-43651430 [accessed April 22, 2021].

- Спеціальна доповідь уповноваженого Верховної Ради України з прав мюдини «Вплив пандемії Covid-19 на ромську громаду в Україні, Київ 2021, 29 c., https:// rm.coe.int/special-report-11-01-2021-ukr/1680a13218 [accessed April, 31, 2021]

- Фаріон I. Результати референдуму у Криму Росія «намалювала», http://wz.lviv. ua/ukraine/126861 [accessed May, 1, 2021] 
- Хирш М.. Что такое постпамять, https://urokiistorii.ru/article/53287 [accessed April 21, 2021]

- Черецький В. та Білик. Іспанія знову перетворюється на осереАок поширення коронавірусу. https://cutt.ly/qkhhDvv [accessed April 21, 2021].

Summary: The XXI century has entered the world history as a time of radical changes in all spheres of life: from political to technological. Moreover, the previous century marked the emergence of virtuality as another reality. This has led to a number of measurable approaches to assessing various historical and political events and the active use of propaganda and manipulative technologies by individual political actors to form a certain worldview and instill values among the population. This article is devoted to the analysis of the impact of the Covid-19 pandemic on information processes in the modern world. The authors draw attention to the peculiarities of the development of modern information technologies and their use in modern times. In particular, the main directions of information influence of the Russian Federation on the political stability of European countries in the context of the Covid-19 pandemic.

Key words: security, Kovid-19 pandemic, information policy, manipulation, propaganda.

\section{Wyzwania bezpieczeństwa współczesności: aktywność informacyjna Federacji Rosyjskiej na tle pandemii COVID-19}

Streszczenie: XXI wiek wkroczył do historii świata jako okres radykalnych zmian we wszystkich dziedzinach życia publicznego: od politycznej do technologicznej. Ponadto w ubiegłym stuleciu pojawiła się wirtualność jako inna rzeczywistość, co z kolei doprowadziło do wielowymiarowości podejść w ocenie różnych wydarzeń historyczno-politycznych oraz do aktywnego stosowania technologii propagandowych i manipulacyjnych przez poszczególnych aktorów politycznych w celu ukształtowania pewnego światopoglądu oraz zaszczepienia odpowiednich wartości wśród ludności. Niniejszy artykuł został poświęcony analizie wpływu pandemii COVID-19 na procesy informacyjne we współczesnym świecie. Autorzy zwracają uwagę na specyfikę rozwoju nowoczesnych technologii informacyjnych oraz ich stosowanie we współczesnych czasach. Mianowicie na podstawowe kierunki wpływu informacyjnego Federacji Rosyjskiej na stabilność polityczną krajów Europy w kontekście pandemii COVID-19.

Słowa kluczowe: bezpieczeństwo, pandemia COVID-19, polityka informacyjna, manipulacja, propaganda. 